Celebes Abdimas: Jurnal Pengabdian Kepada Masyarakat

http://journal.lldikti9.id/CER/index

Vol 2, No, 2, Oktober 2020, pp 58-66

p-ISSN:2656-7938 dan e-ISSN: 2657-1870

DOI: https://doi.org/10.37541/celebesabdimas.v2i2.433

\title{
Pemberdayaan Masyarakat Melalui Pengembangan Ekowisata Pasir Putih Kawasan Goa Janji Desa Mallari Kabupaten Bone Sulawesi Selatan
}

\author{
Emmi Azis', Sirwanti Azizul Marwah ${ }^{2}$, Dian Riani Said ${ }^{3}$ \\ ${ }_{1}^{1}$ Pendidikan Ekonomi, STKIP Muhammadiyah Bone, Indonesia \\ Email: emmiazis@gmailcom \\ 2 Pendidikan Matematika, STKIP Muhammadiyah Bone, Indonesia \\ Email: sirwanti89@gmail.com \\ ${ }_{3}^{3}$ Pendidikan Bahasa Inggris, STKIP Muhammadiyah Bone, Indonesia \\ Email: dianrianisaid89@gmailcom
}

\section{Artikel info}

\section{Article history:}

Received:20-08-2020

Revised:08-09-2020

Accepted:10-10-2020

Publish: 28-10-2020
Keywords:

Pemberdayaan

Masyarakat,

Ekowisata,

diversifikasi

pangan)
Abstrak. Program KKN-PPM dalam bentuk pemberdayaan masyarakat ini bertujuan untuk memberi solusi sekaligus mengedukasi mitra dalam 1) meningkatkan pengetahuan dan keterampilan masyarakat tentang eduwisata yang berpotensi pada pengembangan ekowisata (2) meningkatkan kemampuan mahasiswa dan masyarakat dalam pengolahan pangan 3) meningkatkan pengetahuan dan keterampilan dalam melakukan offset sederhana. Metode kegiatan KKNPPM ini adalah metode persuasif dan edukatif dalam bentuk pelatihan dan pendampingan secara intensif ke Ibu PKK sampai menghasilkan produk olahan perikanan dan pertanian serta pelatihan pembuatan produk offset sederhana dan keterampilan berbahasa dalam memnadu wisatawan kepada Kelompok Sadar Wisata (POKDARWIS). Tahapannya terdiri dari 1) persiapan dan pembekalan mahasiswa KKNPPM, 2) Penyuluhan dan pelatihan kepada mitra, 3) pendampingan dan evaluasi. Program ini dilaksanakan dalam bentuk penyuluhan ,pelatihan dan pendampingan hingga menghasilakan beberapa produk inovasi dengan tetap menonjolkan ciri khas Desa. Untuk Olahan Pangan terdiri dari Amplang Massifa (Mallari Aneka Rasa), Abon ikan Maraasa (Mallari Aneka Rasa) , Mr. Bolkit (Mallari Bolu Ungkit). Untuk Offset sederhana menghasilkan Sablon baju dan gelas karakter. Semua produk inovasi program KKN-PPM yang dihasilkan mampu menjadi produk khas dan dapat dijadikan oleh-oleh wisata serta dapat dimasukkan dalam Aplikasi Visit Malllari yang dapat diakses oleh semua pengguna android

Coresponden author: Emmi Azis

STKIP Muhammadiyah Bone, Indonesia Email: emmiazis@gmail.com artikel dengan akses terbuka dibawah lisensi CC BY -4. 
59| Celebes Abdimas: Jurnal Pengabdian Kepada Masyarakat

\section{PENDAHULUAN}

Kabupaten Bone merupakan salah satu kabupaten yang ada di pesisir timur Provinsi Sulawesi Selatan dengan jarak sekitar $174 \mathrm{~km}$ dari kota Makassar. Luas wilayahnya sekitar 4.559 $\mathrm{km}^{2}$ atau 9.78 \%. Kabupaten Bone tergolong kabupaten yang besar dan luas di Sulawesi Selatan dengan rata-rata jumlah penduduk per km² adalah 165 jiwa (BPS ,2018). Desa Mallari merupakan salah satu desa dari Tujuh Belas (17) desa dan 1 Kelurahan yang ada di Kecamatan Awangpone Kabupaten Bone. Desa Mallari terdiri atas Lima (5) dusun yakni Dusun (1) Mallari, Dusun ( II ) Bacu, Dusun (III) Cempalagi , Dusun (IV) Awangnipa dan Dusun (V) Nipa. yang terletak $\pm 30 \mathrm{~km}$ dari ibukota Kecamatan dan $\pm 20 \mathrm{~km}$ dari ibukota Kabupaten Bone. Penduduk Desa Mallari Tahun 2020 (sumber data : SDDK 2019) + 2959 jiwa. Terdiri dari laki-laki 1425 jiwa sedangkan perempuan 1531 Jiwa. Seluruh penduduk Desa Mallari terhimpun dalam keluarga (rumah tangga) dengan jumlah sebanyak $750 \mathrm{KK}$. Rata-rata anggota keluarga sebesar 4 jiwa .

Masyarakat merupakan komponen utama dalam pembangunan mempunyai peranan penting dalam menunjang pembangunan daerah yang ditujukan untuk mengembangkan potensi lokal yang bersumber dari alam, sosial budaya ataupun ekonomi masyarakat. Hal ini sejalan dengan pendapat Meyers (2019) menyatakan bahwa peran serta masyarakat dalam memelihara sumber daya alam dan budaya yang dimiliki merupakan andil yang besar dan berpotensi menjadi daya tarik wisata. Desa Mallari memiliki berbagai potensi yaitu potensi wisata, potensi perikanan dan potensi pertanian yang perlu untuk dikembangkan menjadi kawasan ekowisata berbasis masyarakat yang berujung pada peningkatan ekonomi masyarakat. Namun kenyataannya yang terjadi adalah besarnya potensi yang ada di desa ini tidak diimbangi dengan pemanfaatan yang optimal oleh masyarakat lokal yang ditandai dengan terbatasnya pengetahuan dan keterampilan masyarakat dalam melakukan pengolahan pangan dan pembuatan paket wisata sehingga produk khas yang bisa dijadikan paket wisata belum pernah disediakan di desa ini.

Salah satu upaya untuk mengembangkan ekowisata guna meningkatkan pendapatan masyarakat yaitu dengan menciptakan produk yang menonjolkan ciri khas . Desa Mallari sudah dikenal sebagai desa wisata yang mayoritas penduduknya berprofesi di bidang pertanian dan perikanan. Olehnya itu pemanfaatan potensi lokal desa dsangat baik untuk mendukung potensi wisata Desa Mallari. Ada beberapa hal yang harus dilakukan oleh desa wisata agar bisa sesuai dengan konsep pembangunan pariwisata berkelanjutan dan berbasis masyarakat yaitu; (1) melakukan usaha-usaha yang bisa menjamin kelestarian sosial-budaya dan lingkungan hidup yang ada dan melindunginya dari berbagai hal yang bisa mengancam keberadaannya; (2) memberikan pendidikan atau pelatihan tetang kepariwisataan terhadap masyarakat lokal dan melibatkan mereka dalam proses perencanaan, pembangunan, pelestarian, dan penilaian atau pengevaluasian terhadap pembangunan pariwisata; (3) menggunakan konsep daya tampung (carrying capacity) dan bukan konsep permintaan (demand) dalam menerima wisatawan dan membangun pariwisata, artinya tidak boleh menerima wisatawan yang melebihi daya tampung dari daya tarik wisata dan tidak menerima seluruh wisatawan berdasarkan permintaan dari pengelola jasa pariwisata seperti hotel, biro perjalanan wisata dan perusahaan yang bergerak dalam aktivitas petualangan karena kedatangan wisatawan yang berlebihan akan berdampak kepada masyarakat lokal dan lingkungan; (4) memberikan informasi dan pendidikan kepada wisatawan dan masyarakat lokal tentang perlunya pelestarian pusaka atau warisan; dan (5) melakukan penelitian dan pengabdian kepada masyarakat secara berkala untuk mengetahui perkembangan dan penyimpangan yang terjadi sehubungan dengan penerapan konsep pembangunan pariwisata berkelanjutan. (Oka Darma dkk, 2017).

Kuliah Kerja Nyata Pembelajaran Pemberdayaan Masyarakat (KKN-PPM) merupakan salah satu kegiatan dalam Perndidikan Tinggi yang diselenggarakan berdasarkan UUD 1945 dan Undang-Undang Nomor 2 Tahun 1989 tentang Sistem Pendidikan Nasional Peraturan Pemerintah Republik Indonesia Nomor 60 Tahun 1999 tentang Pendidikan Tinggi. Pendidikan pada dasarnya merupakan proses pendewasaan dan pemandirian manusia secara sistematis, agar siap menjalani kehidupan secara bertanggung jawab. Menjalani kehidupan secara 
bertanggung jawab berarti berani mengambil keputusan yang bijaksana sekaligus berani menanggung segala konsekuensi yang ditimbulkannya.

Berdasarkan hasil observasi di Desa Mallari bahwa masyarakat khususnya kelompok Ibu PKK belum pernah dibekali pelatihan inovasi pengolahan pangan berupa amplang dan abon ikan yang dikemas dengan kemasan yang menarik dengan nama produk yang menonjolkan nama desa. Begitupula dengan Kelompok Sadar Wisata (POKDARWIS) selama ini belum pernah diberi pelatihan dalam hal edukasi wisata terutama dalam hal memandu wisatawan dan menghasilan produk offset sederhana untuk paket wisata Desa Mallari.

Sejauh ini masyarakat Desa mallari hanya mengenal budi daya ikan di tambak dan bercocok tanam di sawah. Ketidaktahuan mereka dalam hal meningkatkan nilai ekonomi produk perikanan dan pertanian berpengaruh terhadap penghasilan masyarakat setempat. Padahal jika dimanfaatkan dengan baik desa Mallari ini mampu menjadi desa wisata unggul produktif dan sejahtera dengan pengembangan sumberdaya masyarakat dalam membuat produk inovasi yang mampu dijadikan sebagai paket wisata atau dapat diperjualbelikan pada jangkauan yang lebih luas. Kegiatan pemberdayaan masyarakat melalui program Kuliah Kerja Nyata Pembelajaran dan Pemberdayaan Masyarakat (KKN-PPM) ini bertujuan untuk memberikan pengetahuan dan memberdayakan masyarakat Desa Mallari melalui melalui pengembangan ekowisata dalam hal ini lebih difokuskan pada edukasi wisata, pengolahan pangan dan pencetakan offsett sederhana agar dijadikan sebagai produk khas desa. Kegiatan ini merupakan kegiatan padat karya, yaitu kegiatan yang dapat memunculkan mata pencarian baru (alternatif), khususnya bagi masyarakat lokal. Contoh mata pencarian baru yang dapat dikembangkan adalah pemandu wisatawan, bidang kuliner dan souvenir.

Berdasarkan latar belakang permasalahan tersebut, dapat diidentifikasi beberapa permasalahan yakni: 1) kurangnya pengetahuan dan keterampilan masyarakat tentang eduwisata yang berpotensi pada pengembangan ekowisata (2) kurangnya kemampuan masyarakat dalam pengolahan pangan 3) rendahnya pengetahuan dan keterampilan dalam melakukan offset sederhana untuk dijadikan souvenir atau paket wisata.

Berdasarkan rumusan masalah, maka dalam kegiatan PPM-KKN ini, akan dilakukan upaya pemecahan masalah dan strategi pemberdayaan masyarakat yaitu: 1) meningkatkan pengetahuan dan keterampilan masyarakat tentang eduwisata yang berpotensi pada pengembangan ekowisata (2) meningkatkan kemampuan mahasiswa dan masyarakat dalam pengolahan pangan 3) meningkatkan pengetahuan dan keterampilan dalam melakukan offset sederhana. (4) pngembangkan pola pemberdayaan kolaboratif melalui pendampingan dalam transfer keterampilan, modal dan akses pemasaran yang lebih luas.

Peningkatan keterampilan masyarakat dalam hal ini Kelompok Ibu PKK dan kelompok sadar wisata (Pokdarwis) dalam kegiatan pelatihan dan pendampingan yang dilakukan yaitu dengan memberikan penyuluhan pelatihan tentang edukasi wisata dan pembuatan produk khas baik berupa olhan pangan maupun produk sablon baju dan gelas karakter. Kegiatan ini melibatkan Mahasiswa yang telah memiliki pengetahuan dan keterampilan sebelumnya tentang pembuatan produk inovasi tersebut, yang secara langsung akan memberikan pelatihan dan melakukan pendampingan kepada masyarakat/mitra.

Pelatihan atau workshop dan pendampingan yang dilakukan di kelompok Ibu PKK dan kelompok sadar wisata (Pokdarwis) serta masyarakat luas, dengan struktur kegiatan yang telah direncanakan secara sistematis diupayakan dapat meningkatkan animo masyarakat tentang pemanfaatan potensi lokal desa yang kaya akan potensi perikanan, pertanian dan pariwisata. Sehingga dengan pemnaffatan potensi tersebut mampu menciptakan pencaharian baru yang dapat meningkatakan taraf pedapatan masyarakat desa Mallari

\section{METODE}

Program KKN-PPM ini dilaksanakan di desa Mallari Kecamatan Awangpone Kabupaten Boe Provinsi Sulawesi Selatan. Jarak tempuh dari Kota Bone ke lokasi pengabdian $\pm 20 \mathrm{~km}$. Waktu Pelaksanaan program KKN-PPM ini mulai dari seleksi mahasiswa sampai pelaksanaan di lokasi yaitu dari bulan Maret 2020- Agustus 2020. Waktu Pelaksanaan KKN-PPM di lokasi dilakukan 
61| Celebes Abdimas: Jurnal Pengabdian Kepada Masyarakat

selama 1 bulan mulai dari 6 Juli 2020-6 Agustus 2020. Sasaran pelaksanaan program KKN-PPM ini yaitu kelompok Ibu-ibu PKK dan kelompok Sadar Wisata yang masing-masing terdiri dari 10 Anggota yang berpendidikan lulusan SD dan SMA. Ketercapaian tujuan pelaksanaan KKNPPM di Desa Mallari ditentukan melalui pendekatan-pendekatan yang telah dilakukan, yakni melalui beberapa pendekatan yaitu: (1) Model Community Development (CD) yaitu pendekatan yang mengacu pada keterlibatan masyarakat secara langsung sebagai subyek dan obyek kegiatan Pengabdian pada Masyarakat; (2) Persuasif yaitu pendekatan yang bersifat himbauan dan dukungan tanpa paksaan bagi masyarakat untuk terlibat secara aktif dalam kegiatan ini; (3) Edukatif yaitu pendekatan sosialisasi pelatihan dan pendampingan sebagai sarana transfer ilmu pengetahuan untuk pemberdayaan masyarakat; (4) Adapun Metode pelaksanaan pengabdian terdiri dari 4 tahapan yaitu :

1. Persiapan dan pembekalan Mahasiswa KKN-PPM

Kegiatan ini terdiri dari sosialisasi program KKN-PPM hingga dinyatakan mahasiswa dinyatakan lolos seleksi dan menyelesaikan pembekalan KKN-PPM.

2. Penyuluhan

Kegiatan ini dilakukan pada saat mahaisswa sudah melakukan penerimaan di lokasi KKN-PPM. Edukasi kelompok Ibu PKK dan kelompok sadar wisata dilakukan melalui penyuluhan dengan memberikan pemanfaatan akan potensi lokal desa terutama dalam hal pertanian perikanan dan pariwisata

3. Pelatihan

Pelatihan dilakukan dengan terlebih dahulu memperhatikan protokol kesehatan mengingat masih pandemi Covid-19 maka seluruh rangkaian pelatihan diawali dengan pembagian masker, sarung tangan dan hand sanitizer. Selanjutnya adalah pengenalan alat dan bahan baku kemudian dilakukan pelatihan pengolahan pangan dan offsett sederhana. Untuk Olahan Pangan terdiri dari Amplang Massifa (Mallari Aneka Rasa), Abon ikan Maraasa (Mallari Aneka Rasa), Mr. Bolkit (Mallari Bolu Ungkit). Tahapan proses pengolahan pangan yaitu : Persiapan, Pemasakan dan Pengemasan

Pelatihan untuk kelompok sadar wisata dilakukan dengan pelatihan Offset sederhana yang menghasilkan sablon baju dan gelas karakter.

4. Pendampingan

Pemanfaatan hasil pelatihan melalui produksi secara mandiri oleh kelompok Ibu PKK dan Pokdarwis dapat dilihat dari pendampingan yang dilaksanakan. Adapun gambar alur pelaksanaan KKN-PPM sebagai berikut:

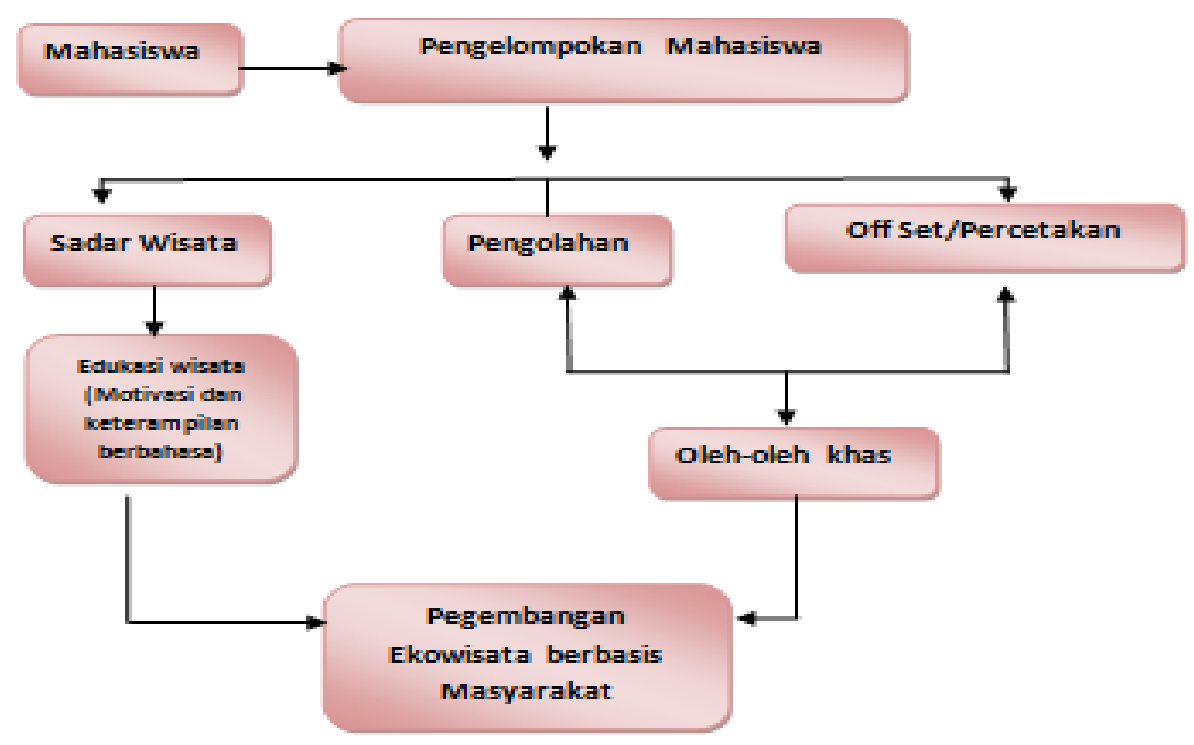

Gambar 1. Alur Pelaksanaan KKN-PPM 
Pelaksanaan KKN-PPM di lokasi pengabdian dilakukan dengan terlebih dahulu melaksanakan seminar singkat dalam bentuk penyuluhan. Penyuluhan dilakukan agar kelompok Ibu PKK dan kelompok sadar wisata dapat memahami potensi lokal yang ada di desa dan mampu memanfaatkan potensi desa sebagai desa wisata dan menghasilkan produk baik produk olahan pangan maupun produk offsett sederhana. Menurut Asfar pada tahun 2019 metode ini disebut dengan Society Parcipatory yaitu pelibatan masyarakat sebagai mitra dalam menyerap keterampilan yang dilakukan dengan cara by doing (Asfar dkk 2019). Penyuluhan ini mampu mengedukasi kelompok ibu-ibu PKK dalam melakukan diversifikasi pangan sehingga menghasilkan produk olahan pangan bernilai ekonomi dan mengedukasi kelompok sadar wisata dalam mengembangkan keterampilan dalam memandu wisatawan sera membuat produk offsett sederhana. Adapunluaran dari pelaksanaan program KKN-PPM ini sebagai Indikator keberhasilan pelaksanaan program pada kelompok Ibu PKK dan Pokdarwis Desa Mallari adalah : (1) Mitra mampu mengetahui bagaimana pemanfaatan potensi lokal desa baik dari sektor pertanian, perikanan maupun pariwisata; (2) Mitra mampu membuat produk olahan khas Desa,; (3) Mulai pengolahan, pengemasan (branding) hingga teknik pemasaran baik offline maupun online, (4) Mitra mampu mengoperasikan alat pengolahan pangan dan offsett sederhana dengan tetap memperhatikan efektifitas tenaga dan waktu.

Metode Evaluasi kegiatan. Kegiatan Tri Dharma Perguruan tinggi di STKIP Muhammadiyah Bone selain ditunjang oleh tenaga pengajar, administrasi dan pengolahan data, juga ditunjang oleh lembaga-lembaga dan unit pelaksana teknis yakni Lembaga Penelitian dan Pengabdian kepada Masyarakat, Lembaga Penjaminan Mutu Perguruan Tinggi, serta lembaga perpustakaan dan penerbitan. Kinerja Lembaga Penelitian dan Pengabdian kepada Masyarakat (LPPM) STKIP Muhammadiyah Bone sebagai lembaga yang menaungi seluruh kegiatan dosen dan mahasiswa dalam pelaksanaan penelitian dan Pengabdian Kepada Masyarakat mengalami peningkatan, khususnya penelitian dan pengabdian dari skema Ditlitabmas-Kemendikbud (KemenristekDikti). Untuk bidang penelitian STKIP Muhammadiyah Bone sudah mengelola dan melaksanakan penelitian yang didanai oleh hibah DP2M dikti antara lain Penelitian Kreativitas Mahasiswa (PKM) dan mampu lolos PIMNAS 32 di Bali , Penelitian Dosen Pemula (PDP)dan Penelitian Desertasi Doktor (PDD).

Pada kegiatan KKN-PPM ini yang menjadi tim pengusul adalah dosen-dosen muda STKIP Muhammadiyah Bone, Ketua Pengusul yaitu Emmi Azis, S.Pd., M.Pd. yang merupakan Dosen Pendidikan Ekonomi dengan Bidang ilmu/Keahlian Pendidikan Ekonomi, Anggota Pengusul yaitu Sirwanti, S.Pd., M.Pd. yang merupakan Dosen Pendidikan Matematika dengan Bidang Ilmu/Keahlian Pendidikan Matematika, Anggota pengusul ke-2 yaitu Dian Riani Said, S.Pd.,M.Pd. yang merupakan Dosen Pendidikan Bahasa Inggris dengan Bidang Ilmu/Keahlian Pendidikan Bahasa Inggris

\section{HASIL DAN PEMBAHASAN}

\section{Persiapan}

Pelaksanaan kegiatan KKN-PPM berbasis pemberdayaan masyarakat merupakan hal baru bagi mahasiswa STKIP Muhammadiyah Bone, tentunya hal ini perlu persiapan dan pembekalan yang matang sehingga akan memudahkan mahasiswa dalam memahami teknis pelaksanaan di lapangan. Pada tahap awal pelaksanaan kegiatan program KKN-PPM dimulai dengan kegiatan sebagai berikut : 1) melakukan koordinasi Pengelola KKN yaitu P2KKN STKIP MUHAMMADIYAH BONE, LPPM beserta anggota tim KKN-PPM. 2) Koordinasi dan pengurusan perijinan dengan Kepala Desa Mallari dan Camat Kecamatan Awangpone, Kabupaten Bone, Sulawesi Selatan. 3) penyampaian informasi dan pendaftaran program KKN-PPM dengan berupa sosialisasi program baik offline maupun online.4) Mahasiswa kemudian melakukan pendaftaran dan pihak P2KKN melakukan seleksi dan tim pelaksana mengumumkan nama-nama mahasiswa yang lolos KKN-PPM. 5) Pembekalan bagi mahasiswa yang telah lolos seleksi berupa materi program KKN-PPM dan teknik-teknik sosialisasinya dimasyarakat. 6) Pembagian 
63 | Celebes Abdimas: Jurnal Pengabdian Kepada Masyarakat

kelompok/posko KKN PPM dan kemudian dilakukan pelepasan mahasiswa ke lokasi KKN-PPM yaitu Desa Mallari Kecamatan Awangpone

Kegiatan pembekalan KKN-PPM dilaksanakan selama 3 hari dan wajib diikuti oleh semua peserta KKN PPM yang telah dinyatakan lolos seleksi. Materi Pembekalan terdiri atas materi khusus dan materi umum. Materi khusus berkaitan dengan kegiatan inti pelaksanaan KKN PPM di Lapangan. Materi tersebut diantaranya 1) Materi edukasi wisata termasuk pemberian motivasi dan pelatihan teknik memandu wisatawan, 2) Materi potret masyarakat petani dan nelayan bertujuan memberikan gambaran kepada mahasiswa tentang pembelajaran dan kondisi kehidupan masyarakat kehidupan petani dan nelayan/petambak, 2) Materi tahapan pembuatan aneka produk diversifikasi pangan bertujuan agar mahasiswa mengetahui tahapan pembuatan aneka produk diversifikasi olahan perikanan dan pertaniaan meliputi pembuatan abon ikan, amplang ikan dan bolu cukke yang merupakan kue tradisional khas bugis yang berbahan dasar tepung beras, 3) Materi Pengemasan dan Pemasaran, bertujuan agar mahasiswa mengetahui teknik pengemasan (branding) yang baik dan strategi pemasaran produk

Materi umum kegiatan pembekalan berkaitan dengan pelaksanaan KKN PPM secara umum. Materi tersebut diantaranya 1) Filosofi KKN-PPM (Kuliah Kerja Nyata Pembelajaran Pemberdayaan Masyarakat) bertujuan agar Mahasiswa mampu menanamkan nilai-nilai nasionalisme, kepribadian, keuletan, etos kerja, tanggung jawab, kemandirian, kepemimpinan, kewirausahaan, dan penanaman jiwa kepengabdian pdada masyarakat. 2) Berpikir Kreatif dan Inovatif dalam memecahkan persoalan di masyarakat bertujuan agar mahasiswa mampu berpikir kreatif dan inovatif dalam memecahkan persoalan di masyarakat. 3) Etika Pergaulan di masyarakat bertujuan agar mahasiswa mampu mengetahui etika dalam melakukan pergaulan pada masyarakat, 4) Penyusunan program kerja, laporan dan Penilaian KKN-PM, diharapkan mahasiswa mampu membuat dan menyusun program kerja dan laporan KKN-PPM

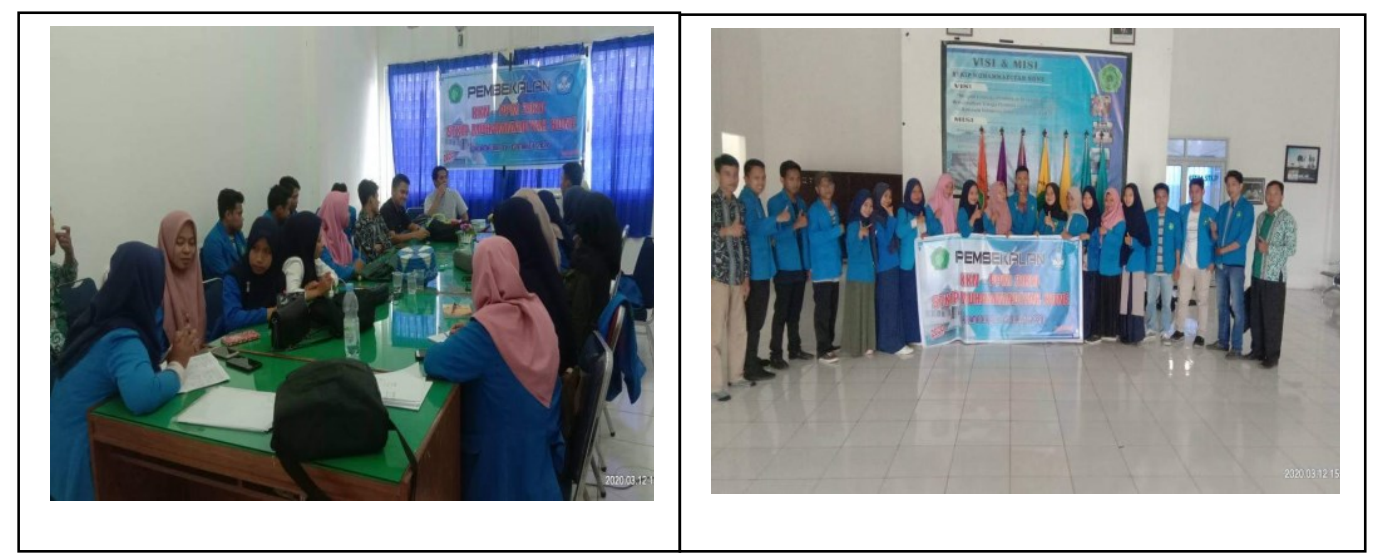

Gambar 1 Proses Pembekalan KKN-PPM

\section{Penyuluhan}

Penyuluhan dilakukan setelah tim pelaksana melakukan observasi sebagai bentuk sosialisasi kepada mitra dan warga desa Mallari akan pelaksanaan program KKN-PPM yang akan dilaksanakan. Dengan adanya pendekatan tersebut akan memberikan pengaruh positif dan akan mengundang antusias mitra dan warga yang berada di sekitar lokasi pelaksanaan KKN-PPM. Kegiaatan penyuluhan memberikan ruang untuk mengedukasi mitra kelompok Ibu PKK dan Pokdarwis dalam meningkatkan pengetahuan dan keterampilan dalam edukasi wisata, pengolahan pangan dan offsett sederhana. Pemanfaatan bahan-bahan yang ada di sekitar dengan memberikan sentuhan inovasi memberi ketertarikan tersendiri kepada mitra. Pelatihan ini memberikan manfaat bagi kelompok Ibu PKK dan Pokdarwis serta masyarakat luas mengenai pemanfaatan potensi lokal desa Mallari. Seluruh jenis produk yang dihasilkan bisa dijadikan sebagai produk khas desa dan dapat dijadikan oleh-oleh wisata yang memiliki nilai ekonomis tinggi dan menciptakan pengembangan ekowisata. 


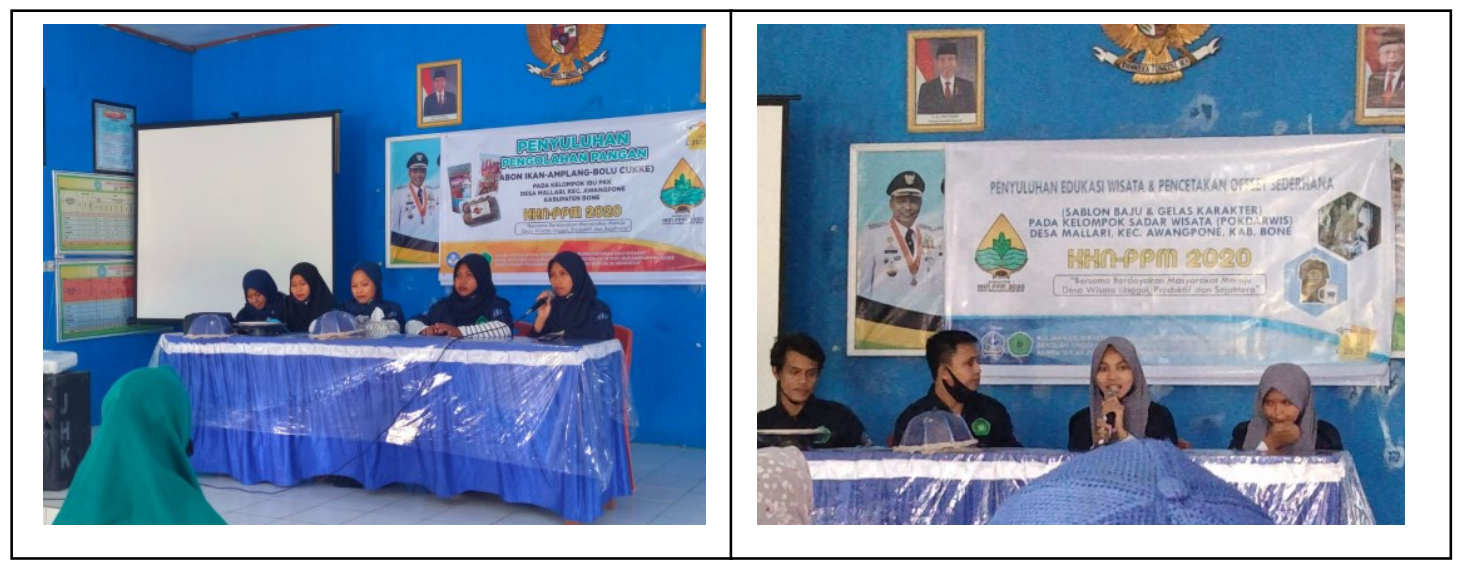

Gambar 2 Penyuluhan pengolahan pangan, offsett sederhana dan edukasi wisata

\section{Pelatihan}

Pada Pelaksanaan Program KKN-PPM ini mahasiswa dibagi menjadi tiga kelompok / posko dan ditempatkan di tiga dusun yang telah dipilih yaitu dusun Mallari, dusun Bacu, dan dusun Cempalagi. Program kerjanya terdiri dari pelatihan keterampilan bahasa dalam memandu wisatawan (edukasi wisata ), pelatihan pengolahan pangan (hasil pertanian dan perikanan) , dan pencetakan offsett sederhana berupa sablon baju dan gelas karakter.

Keterlibatan langsung Mahasiswa dan DPL sangat berpengaruh pada proses pelatihan masyarakat demi meningkatnya pengetahuan keterampilan ekowisata. Pemanfaatan bahanbahan yang ada di sekitar menjadikan masyarakat sangat antusias dengan pelatihan ini. Pelatihan ini sangat memberikan manfaat bagi kelompok Ibu PKK dan Pokdarwis serta masyarakat luas mengenai pemanfaatan potensi lokal desa Mallari.

Mahasiswa yang berpartisipasi dalam kegiatan KKN PPM berjumlah 22 orang yang berasal dari disiplin ilmu yang berbeda-beda. Dengan adanya pelatihan kepada mahasiswa peserta KKN PPM sebelum ke lokasi kegiatan, mereka dapat mendampingi masyarakat dalam pelatihan pengolahan pangan, ofsett sederhana dan edukasi wisata secara baik, meskipun masih ada kendala yang ditemukan.

Pelaksanaan program meliputi proses pengenalan alat dan bahan, pelatihan pembuatan, pelatihan pengemasan dan keberlanjutan program oleh masyarakat Desa Mallari. Proses penyuluhan dilakukan secara menyeluruh dengan pembahasan seluruh program yang akan dilaksanakan untuk mengefisienkan waktu di tengah kondisi COVID-19. Pelaksanaan masing-masing program, baik pada pengolahan pangan, pencetakan offset dan pelatihan edukasi wisata dilaksanakan selama tiga kali pertemuan.

Pelaksanaan pengolahan pangan mengacu pada kelompok Ibu PKK yang memiliki waktu luang dan sangat berpotensi sebagai mitra. Adapun fokus pada pelatihan pencetakan offset dan edukasi wisata mengacu pada Kelompok Sadar Wisata (POKDARWIS) Desa Mallari. Tiga hari setelah pelaksanaan penyuluhan program dilakukan persiapan untuk mengadakan pelaksanaan pengolahan pangan. Pembuatan Mr. Bolkit, Amplang Massifa dan Abon Ikan Maraasa dilakukan secara terpisah untuk memberikan masyarakat waktu yang efektif dalam memahami program. Pelaksanaan pelatihan pencetakan offset dilaksanakan setelah tiga hari pelaksanaan pengolahan pangan, dimulai dari pengenalan alat dan bahan yang digunakan, pelatihan pembuatan sablon baju dan gelas karakter, serta pelatihan pemasaran produk. Program terakhir yang dilaksanakan adalah pelatihan edukasi wisata kepada Kelompok Sadar Wisata (POKDARWIS) Desa Mallari. 
65 | Celebes Abdimas: Jurnal Pengabdian Kepada Masyarakat
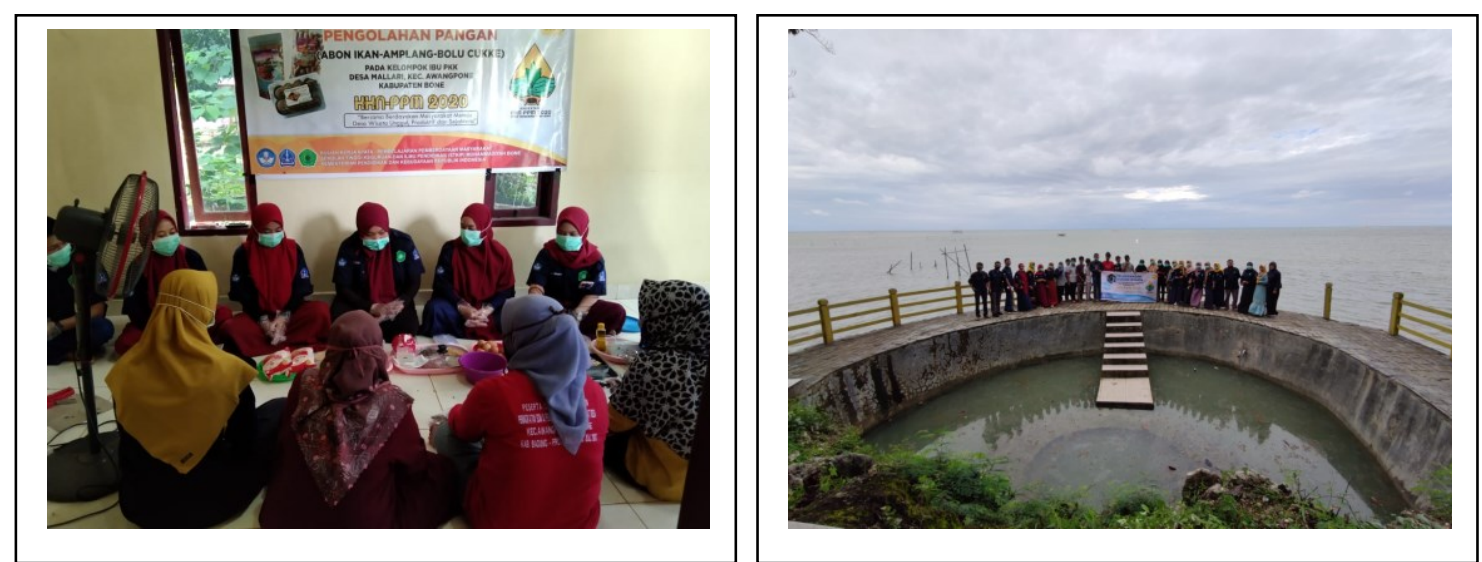

Gambar 3 Pelaksanaan pelathan pengolahan Pangan dan Edukasi Wisata

\section{Pendampingan}

Pendampingan dilaksanakan agar permasalahan mitra setelah pelatihan dilaksanakan dapat ditemukenali oleh tim KKN-PPM (Gambar 4). Pendampingan dimaksudkan pula untuk mengevaluasi kemampuan mitra dalam membuat produk olahan pangan,offsett sederhana dan edukasi wirdalam hal keterampilan dalam memandu wisatawan. Untuk Monitoring keberlanjutan program dilakukan secara offline dan online.Mengingat masih dalam kondisi pandemik covid-19 sehingga mahasiswa membentuk Grup WhatsApp dan link Aplikasi Zoom untuk memonitoring perkembangan mitra dalam melakukan pengolahan pengemasan hingga pemsaran produk. Berdasarkan hasil pendampingan secara langusng di lokasi ternyata mitra telah mampu membuat hasil olahan pangan, offsett sederhana dan sudah cukup terampil dalam hal kebahasaan dalam memandu wisatawan.
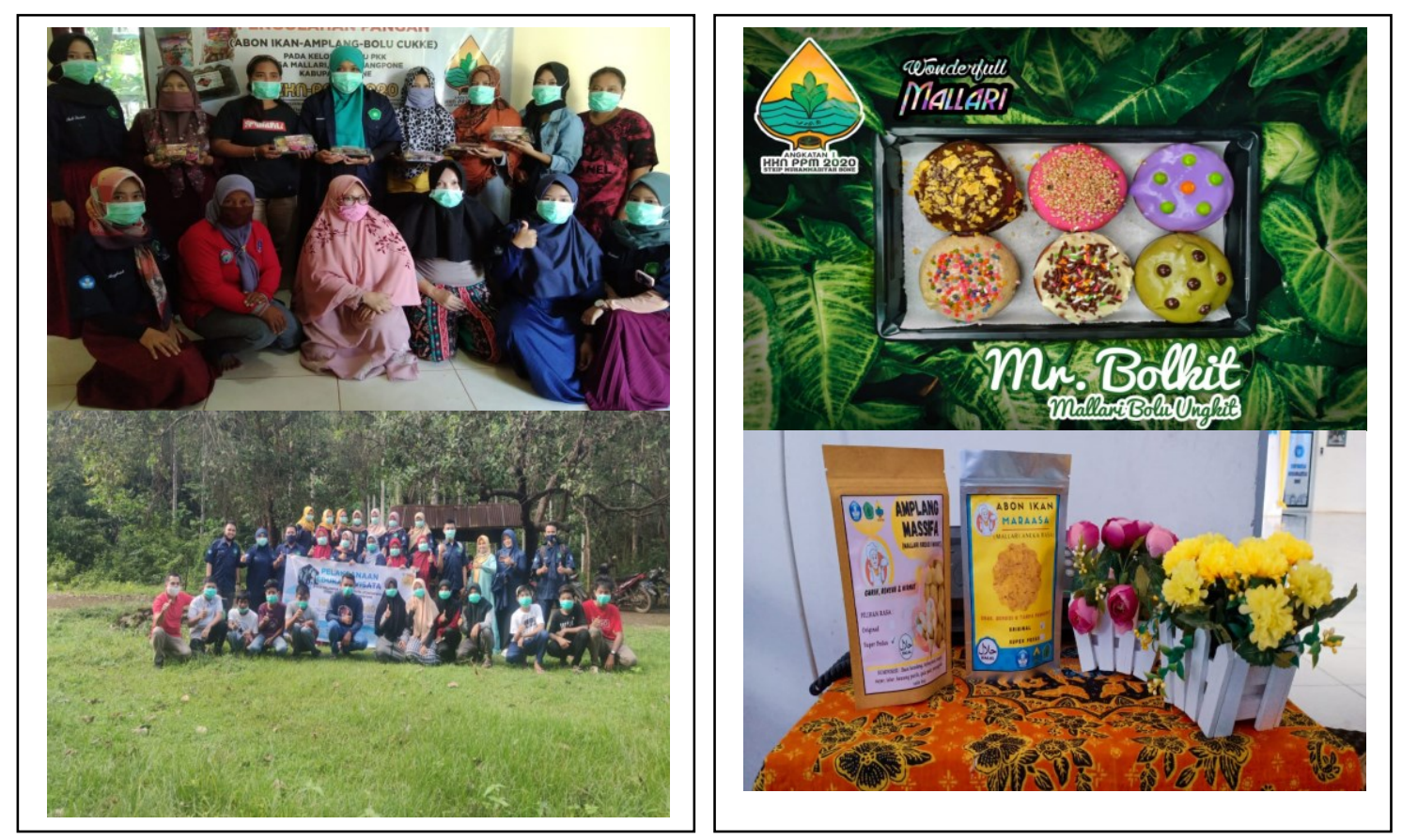

Bentuk keberhasilan pelaksanaan program KKN PPM dapat dilihat dari terciptanya sebuah aplikasi android yaitu Visit Mallari. Aplikasi ini dilengkapi dengan berbagai fitur yang memungkinkan untuk memperkenalkan beberapa destinasi wisata yang ada di Desa Mallari. Selain itu, hasil pengolahan pangan dan pencetakan offset juga dapat diperkenalkan secara meluas dan dipasarkan melalui aplikasi ini. Pelaksanaan KKN-PPM mendapatkan respon positif dan manfaat berarti bagi mitra terlihat dari antusias mereka dalam melakukan praktik keberlanjutan program yang telah dilaksanakan oleh tim KKN-PPM dan memasarkannya 
secara luring dan daring.

\section{SIMPULAN DAN SARAN}

KKN-PPM Pemberdayaan masyarakat melalui pengembangan ekowisata di desa Mallari dapat meningkatkan pengetahuan dan keterampilan peserta pelatihan kelompok Ibu PKK dan Pokdarwis dalam melakukan pembuatan produk khas yang mampu meningkatkan perekonomian masyarakat setempat. Produk yang dihasilkan nanti dapat dipasarkan melalui BumDes, dipasarkan di sekitar tempat wisata atau melalui via online. Berdasarkan hasil monitoring dan evaluasi mitra telah memiliki pengetahuan dan keterampilan dalam membuat produk yang telah diajarkan.

\section{UCAPAN TERIMA KASIH}

Ucapan terimakasih kepada Kementerian Pendidikan dan Kebudayaan (Kemendikbud), Kementerian Riset, Teknologi/ Badan Riset dan Inovasi Nasional (Ristek/ BRIN) Hibah Program Kuliah Kerja Nyata Pembelajaran dan Pemberdayaan Masyarakat (KKN PPM) tahun 2020,, LPPM STKIP Muhammadiyah Bone, Pemerintah Daerah Kabupaten Bone, dan Pemerintah Kecamatan Awangpone, Pemerintah Desa Mallari, Kelompok Ibu PKK, BumDes Assingkerukeng serta Pokdarwis Desa Mallari sebagai mitra kegiatan KKN PPM.

\section{DAFTAR RUJUKAN}

Asfar, A.M.I.A., Arifuddin, W., \& Rahman, A. (2019). Pengolahan Kayu Sepang Di Desa Biru Kecamatan Kahu Kabupaten Bone. Jurnal Panrita Abdi, 3(2), 97-104.

Badan Pusat Statistik 2018. Statistik Daerah Kabupaten Bone. Watampone: Badan Pusat Statistik Kabupaten Bone. Katalog : 1101002.7311.

Meyers, K. (2009). Ekowisata : Panduan Dasar Pelaksanaan. UNESCO Office, Jakarta.

Oka, D.M.I, Winia,N.I, \& Pugra,W.I. (2017). Pemberdayaan Masyarakat melalui Pelatihan Pengolahan Masakan Seafoods untuk Menunjang Pariwisata di desa Wisata Serangan 